\title{
Eco-friendly Management of Rust of Field Pea (Pisum sativum L.)
}

\author{
S. Mounika Reddy ${ }^{*}$, Indarapu Madhuri and Shashi Tiwari \\ Department of Plant Pathology, Sam Higginbottom University of Agriculture Technology and \\ Sciences Prayagraj, Uttar Pradesh, India \\ *Corresponding author
}

\section{A B S T R A C T}

\section{Keywords}

Essential oils, Neem oil, Pea,

Trichodermaviride, Clove oil, Castor oil, Rust

\section{Article Info}

Accepted:

07 November 2020

Available Online:

10 December 2020
An experiment was conducted at Sam Higginbottom University of Agriculture, Technology and Sciences, Allahabad, Uttar Pradesh in Rabi season of 2019-20. A field experiment was conducted in RBDto evaluate different essential oils, one bio-agent and their combinations to control rust disease of pea and also to increase the plant growth parameters. During evaluation, all the seven treatments Viz. Neem oil (5\%), Castor oil (5\%), Clove oil (5\%), Trichoderma viride (5\%), T. viride + Neem oil $(2.5 \%+2.5 \%), T$. viride+ Castor oil $(2.5 \%+2.5 \%)$ and $T$. viride+ Clove oil $(2.5 \%+2.5 \%)$ were found to be significantly superior over control in managing the rust disease and also in increasing the growth parameters. Among the treatments $\mathrm{T}_{5^{-}} T$. viride + Neem oil $(2.5 \%+2.5 \%)$ followed by $\mathrm{T}_{1}$-Neem oil $(5 \%)$ and $\mathrm{T}_{4}$ - Trichoderma viride $(5 \%)$ were significantly superior over other treatments in managing rust disease of the crop and also in increasing the growth parameters. During evaluation, Trichoderma viride at $2.5 \%$ in combination with neem oil at $2.5 \%$ was found as best treatment to control rust disease and also to increase the growth parameters.

\section{Introduction}

Pea (Pisum sativum L.) is a valuable vegetable as well as pulse crop all over the world, is also known as 'Matar'. It belongs to the family Leguminoceae and a selfpollinated crop (Anonymous, 2004).

Globally, pea is grown in an area of 1.2 million ha with total production of 9.3 million tonnes and the productivity is 8.42 tonnes/ ha. India is the second largest pea producing countryand shares 21 percent production of world. In India, it occupies 5.43 lakh hectare area with annual production around 54.32 lakh metric tonnes and productivity of 46.51 lakh metric tonnes (Indian Horticulture Database, 2017-2018). It is cultivated mainly in Uttar Pradesh and it alone produces $60.78 \%$ more than half of the total production of pea. Besides this, Madhya Pradesh, Jharkhand, Punjab, West Bengal, Haryana, Bihar, and Himachal Pradesh are also major pea producing states (Subrahmanyam and Gaganana, 2000) where it is grown for both vegetable and pulse purpose and is a highly remunerative crop (Singh, 2005).

Pea is cultivated for the fresh green seeds, tender green pods, dried seeds and foliage and 
cooked as a vegetable, marketed fresh canned and frozen. Dry peas are used as whole, spilt as dal, roasted, boiled and made into flour (Davies et al., 1985).

Among the fungal diseases rust caused by Uromycesfabae is the major disease of pea and cause severe damage and which is responsible to reduction in yield throughout the world. Yield reduction due to this disease is very high within short period of time. It is macrocyclicautoecious rust (Singh and Tripathi, 2004). The average yield of pea is quite low as compared to its yield potential. They cause about 30-40\% loss anually (Singh, 1999; Upadhyay and Singh, 1994).

\section{Materials and Methods}

The effective essential oils, one bio-agent and their combinations were evaluated under field condition. Field experiments were laid-out in Randomized Block Design with three replications at research plot of the Department of Plant Protection, Sam Higginbottom Institute of Agriculture Technology and Sciences, Allahabad during the Rabi season of 2019-20.

The seed variety AP-3 were sown @ 20-25 $\mathrm{kg} / \mathrm{ha}$ by dibbling method with spacing of 30 $\mathrm{cm}$ between row to row and $10 \mathrm{~cm}$ between plant to plant by placing 2 seeds per hill at depth of $4 \mathrm{~cm}$. Sowing was done on 20th of December. Yield - kg/plot.

Seed treatment was done by taking pea seeds in separate conical flasks and then essential oils viz. Neem oil, Castor oil, Clove oil and one bio-agent viz. Trichoderma viride were taken at 5\% concentration accordingly and poured. For combinations oil and $T$. viride were taken $5 \%$ each. The flasks were shaken by hand for 5minutes until the seeds were saturated. In control, seeds were planted with no treatment (Hashem et al., 2010).

\begin{tabular}{|c|c|c|}
\hline Treatment No. & Treatment Name & Concentration \% \\
\hline $\mathbf{T}_{\mathbf{0}}$ & Control & - \\
\hline $\mathbf{T}_{\mathbf{1}}$ & Neem oil & $5 \%$ \\
\hline $\mathbf{T}_{\mathbf{2}}$ & Castor oil & $5 \%$ \\
\hline $\mathbf{T}_{\mathbf{3}}$ & Clove oil & $5 \%$ \\
\hline $\mathbf{T}_{\mathbf{4}}$ & Trichoderma viride & $5 \%$ \\
\hline $\mathbf{T}_{\mathbf{5}}$ & T. viride+ Neem oil & $2.5 \%+2.5 \%$ \\
\hline $\mathbf{T}_{\mathbf{6}}$ & T. viride + Castor oil & $2.5 \%+2.5 \%$ \\
\hline $\mathbf{T}_{\mathbf{7}}$ & T. viride + Clove oil & $2.5 \%+2.5 \%$ \\
\hline
\end{tabular}

\section{Disease intensity for rust}

Observations on rust disease intensity were recorded on randomly selected plants from the each bottom, middle and top leaves. The disease intensity was recorded on pea plant at 30 days, 60 days and 90 days after seed treatment. Five plants in each plot were tagged and disease intensity for field pea rust was calculated by the formula as employed by wheeler (1969). Data was subjected to ANOVA test.

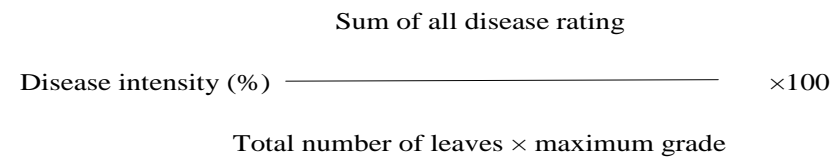




\section{Results and Discussion}

Effect of treatments on plant growth parameters of field pea at different intervals

The readings for plant growth parameters include height, no. of leaves, number of branches were taken on 30,60 and 90 DAS. The essential oils have some antifungal properties, so the treatments showed their action in the in vivo experiment. The experiment showed that $\mathrm{T}_{5} T$. viride $+\mathrm{Neem}$ oil gave the best result in turns of height, no. of leaves, maximum number of branches followed by $\mathrm{T}_{1}$ neem oil. At $90 \mathrm{DAS}$, the data showed maximum height of $85.38 \mathrm{~cm}, 64.17$ no. of leaves and 3.36 branches in $\mathrm{T}_{5}$ treatment followed by $\mathrm{T}_{1}$-height of $83.17 \mathrm{~cm}$, 56.32 no. of leaves and 3.31branches and T6height of $81.28 \mathrm{~cm}, 53.70$ no. of leaves and 3.27 branches.

Table.1 Effect of treatments on per cent disease index of rust on field pea at different intervals

\begin{tabular}{|l|c|c|c|c|}
\hline \multicolumn{2}{|l|}{ Treatment name } & \multicolumn{3}{|c|}{ PDI (\%) } \\
\cline { 2 - 5 } & $\mathrm{T}_{0}$ & 24.35 & 54.25 & 69.13 \\
\hline Control & $\mathrm{T}_{1}$ & 19.84 & 26.66 & 34.25 \\
\hline Neem oil & $\mathrm{T}_{2}$ & 24.15 & 38.08 & 44.54 \\
\hline Castor oil & $\mathrm{T}_{3}$ & 22.42 & 35.78 & 41.56 \\
\hline Clove oil & $\mathrm{T}_{4}$ & 19.87 & 28.27 & 35.52 \\
\hline Trichoderma viride & $\mathrm{T}_{5}$ & 19.82 & 25.57 & 27.77 \\
\hline $\boldsymbol{T}$. viride + Neem oil & $\mathrm{T}_{6}$ & 20.18 & 33.43 & 40.86 \\
\hline T. viride+ Castor oil & $\mathrm{T}_{7}$ & 19.91 & 30.42 & 38.46 \\
\hline $\boldsymbol{T}$. viride + Clove oil & & $\mathbf{S}$ & $\mathbf{S}$ & $\mathbf{S}$ \\
\hline F test & & $\mathbf{0 . 0 7}$ & $\mathbf{1 . 0 4}$ & $\mathbf{0 . 9 6}$ \\
\hline CD $(\mathbf{0 . 0 5})$ & & $\mathbf{0 . 4 5}$ & $\mathbf{0 . 4 8}$ & $\mathbf{0 . 4 5}$ \\
\hline SEd $( \pm)$ & & & & \\
\hline
\end{tabular}

Table.2 Economics of treatments

\begin{tabular}{|c|c|c|c|c|c|c|}
\hline Treatment details & $\begin{array}{c}\text { Yield/ha } \\
\text { (q/ha) }\end{array}$ & $\begin{array}{c}\text { Market } \\
\text { Value } \\
\text { (Rs/q) }\end{array}$ & $\begin{array}{c}\text { Total } \\
\text { income } \\
\text { (Rs) }\end{array}$ & $\begin{array}{c}\text { Cost of } \\
\text { production } \\
\text { (Rs) }\end{array}$ & $\begin{array}{c}\text { Net } \\
\text { return } \\
\text { (Rs) }\end{array}$ & $\begin{array}{c}\text { C:B } \\
\text { ratio }\end{array}$ \\
\hline Control & 11.55 & 4000 & 46200 & 27500 & 18700 & $1: 1.38$ \\
\hline Neem oil & 19.14 & 4000 & 76560 & 28400 & 48160 & $1: 2.69$ \\
\hline Castor oil & 14.03 & 4000 & 56120 & 28700 & 27420 & $1: 1.95$ \\
\hline Clove oil & 16.03 & 4000 & 64120 & 29000 & 35120 & $1: 2.21$ \\
\hline Trichoderma viride & 18.72 & 4000 & 74880 & 28500 & 46360 & $1: 2.62$ \\
\hline T. viride+ neem oil & 20.07 & 4000 & 80280 & 28450 & 51830 & $1: 2.82$ \\
\hline T. viride+castor oil & 17.49 & 4000 & 69960 & 28600 & 41360 & $1: 2.44$ \\
\hline T. viride+clove oil & 18.02 & 4000 & 72080 & 28800 & 43280 & $1: 2.50$ \\
\hline
\end{tabular}


Effect of treatments on disease intensity (\%) of rust (Uromycesfabae) on field pea at different intervals

The data for disease intensity was also taken with growth parameters at 30,60 and 90 DAS and furnished in Table 1.

The data of 30 DAS showed the minimum disease intensity in the treatment $\mathrm{T}_{5} T$. viride + Neem oil $(19.82 \%)$ followed by the treatment $\mathrm{T}_{1}$ Neem oil $(19.84 \%)$ and $\mathrm{T}_{4}$ Trichoderma viride (19.87\%), where $\mathrm{T}_{0}$ Control had the maximum disease intensity (24.35\%).

The data of 60 DAS showed the minimum disease intensity in the treatment $\mathrm{T}_{5} T$. viride+Neem oil $(25.57 \%)$ followed by the treatment $\mathrm{T}_{1}$ Neem oil $(26.66 \%)$ and $\mathrm{T}_{4}$ Trichoderma viride (28.27\%), where $\mathrm{T}_{0}$ Control had the maximum disease intensity $(54.25 \%)$.

The data of 90 DAS showed the minimum disease intensity in the treatment $\mathrm{T}_{5} T$. viride + Neem oil $(27.77 \%)$ followed by the treatment $\mathrm{T}_{1}$ Neem oil $(34.25 \%)$ and $\mathrm{T}_{4}$ Trichoderma viride $(35.78 \%)$ where $\mathrm{T}_{0}$ Control had the maximum disease intensity $(69.13 \%)$.

Similar findings were reported by Sughaet al., (1999), Mathur and Gurjar (2002),Ononkoba (2002) and Ahmed and Shaheen (2016). They evaluated the efficacy of Trichoderma viride alone and in combination with essential oils against pea rust disease intensity of field pea (Pisumsativum L.) in field condition. Minimum disease intensity (\%) was found in Trichoderma viride in combination with neem oil. The probable reason for such finding may be their inhibitory effects on rust development appeared to be due to production of antibiotic metabolites that inhibited spore germination and formation of rust pustules. The secondary metabolites such as alkaloids, phenolics and terponoids of neem oil also inhibit the growth of the pathogen.

\section{Economics of treatments}

The data on cost benefit ratio of field pea are furnished in table 2 .

The yields among the treatment were significant. Among all the treatments the maximum yield $(\mathrm{q} / \mathrm{ha})$ was recorded in $\mathrm{T}_{5^{-}} T$. viride+ neem oil (20.07) followed by $\mathrm{T}_{1-}$ Neem oil (19.14), $\mathrm{T}_{4}$-Trichoderma viride (18.72), $\mathrm{T}_{7}-$ T. viride+ Clove oil (18.02), $\mathrm{T}_{6}-$ T. viride+ Castor oil (17.49), $\mathrm{T}_{3}-$ Clove oil(16.03) and $\mathrm{T}_{2}-$ Castor oil (14.03) as compared to $\mathrm{T}_{0}$-control (11.55). When cost benefit ratio was worked out, interesting result was achieved. From the cost benefit ratio it was concluded that most effective treatment was $\mathrm{T}_{5^{-}}$treatment $T$. viride+ neem oil (1:2.82) followed by $\mathrm{T}_{1^{-}}$Neem oil (1:2.69), $\mathrm{T}_{4}$-Trichoderma viride (1:2.62), $\mathrm{T}_{7^{-}}$ T. viride+ Clove oil (1:2.50) and least effective treatment was $\mathrm{T}_{2^{-}}$Castor oil (1:1.95). However all treatments were superior to the control with respect to the cost benefit ratio in managing rust disease.

From present study, it was concluded that $T$. viride $(2.5 \%)+$ Neem Oil $(2.5 \%)$ was found as best treatment for the increase in growth parameters of field pea crop. This treatment is also effective in the control of rust disease caused by Uromyces fabae. From cost benefit ratio also this treatment was found as most economic method over control. Since chemicals have many hazardous effects on the environment as well as the person who handles it while application in the field, Trichoderma viride + Neem Oil would be considered as better as it is eco-friendly. Since one year data is not sufficient to conclude concurrent results, further experimentations are required to confirm the results. 


\section{References}

Ahmed, M. F. A. and Shaheen, S. I. (2016). Evaluation of some Trichoderma isolates to control cowpea rust and increase crop productivity. International Conference of Applied Microbiology, pp. 250-258.

Davies, D.R., Berry, G. J., Heath, M.C. and Dawkins, T.C.K. (1985). "The Grain legume crops". Williams Collins Sons and Co. Ltd, London, UK, pp. 147198.

Hashem, M., Mohram, A. M., Zaied, A. A. and Saleh, F. E. M. (2010). Efficacy of essentials oils in the control of Cumin root rot disease. Crop protection, 10(29): 1111- 1117.

Mathur, K. and Gurjar, R.B.S. (2002). Evaluation of different fungal antagonists plant extracts and oil cakes against Uromyces fabae. Annual Plant Protection Sciences, 12: 83-86.

Ononkoba, M. (2002). Studies on control of French bean rust caused by Uromyces appendiculatus (pers.) using fungal and bacterial metabolites. M.Sc., in Plant Pathology, Thesis. University of
Nairobi Research.

Singh K. (2005). Development of sustainable farming system model for irrigated agro-ecosystem of eastern UP, ICAR, Adhoc project final report, New Delhi.

Singh, D. and Tripathi, H.S. (2004). Epidemiology and management of field pea rust, Journal of Mycological Plant Pathology, 34 (2): 675-79.

Singh, R.S. 1999. Plant Diseases. Oxford and IBH. New Delhi, pp 686.

Subrahmanyam, K.V. and Gaganana, T.M. (2000). Cooperative marketing of fruits and Vegetables in India. Concept publishing company, New Delhi, p.1730

Sugha, S.K., Banyal D.K. and Rana S.K. (1999). Management of pea (Pisum sativum) rust (Uromyces fabae). Indian Journal of Agricultural Sciences, 78:269-71

Upadhyay, A.L. and Singh, V.K. 1994. Performance of pea varieties/lines against powdery mildew and rust. Ann. Agricul. Res., 7: 92-93.

Wheeler, B.E.J. 1969. An Introduction to Plant Disease, John Wiley Sons Ltd., London, pp. 301.

\section{How to cite this article:}

Mounika Reddy, S., Indarapu Madhuri and Shashi Tiwari. 2020. Eco-friendly Management of Rust of Field Pea (Pisum sativum L.). Int.J.Curr.Microbiol.App.Sci. 9(12): 660-664. doi: https://doi.org/10.20546/ijcmas.2020.912.079 